\title{
Integration Policies of European Cities in Comparative Perspective: Structural Convergence and Substantial Differentiation
}

DOI: 10.11567/met.32.2.1

UDK: 314.742(4-EU)

316.4.063.4-054.72(4-EU)

Izvorni znanstveni rad

Primljeno: 02. 03. 2016.

Prihvaćeno: 17. 10. 2016.

\author{
Rinus Penninx
}

Faculteit der Maatschappij- en Gedragswetenschappen Afdeling Sociologie en

Antropologie, Universiteit van Amsterdam, Amsterdam

M.J.A.Penninx@uva.nl

\section{Blanca Garcés-Mascareñas \\ CIDOB - Barcelona Centre For International Affairs, Barcelona \\ blanca.graces@upf.edu}

\begin{abstract}
SUMMARY
This article aims to review the comparative study of integration policies of European cities. The first two sections present an analytical framework for the study of immigrants' integration processes and the policies that intend to steer such processes. The third section outlines how local integration policies have developed in relation to national policies and EU integration policies, particularly after 2003. The fourth and main section analyses the framing and content of integration policies of European cities, looking at their diversity in the legal/political dimension, the socio-economic dimension - including the domains of work, housing, education and health - and the cultural, religious and ethnic dimension. It is concluded that there is a structural convergence, in the sense that in the complex structure of multilevel governance of migration and integration, cities do take a similar position, developing horizontal relations of cooperation and exchange. Cities that develop explicit integration policies tend to do this from a more inclusive and pragmatic framing than national and EUpolicies. At the same time, there is great variation in what cities actually do: in the legal/political and in the cultural/religious dimensions, framing, intentions and measures do vary greatly; in the socio-economic dimension this variation is less when it comes to the domains of activity, but more in the intensity of policy intervention.
\end{abstract}

KEY WORDS: migrant policy, local integration policy, multi-level policies 


\section{INTRODUCTION}

In the study of integration policies the national level of individual countries has been the dominant unit of analysis. In such studies the integration policies towards newcomers, or in the absence of an explicit policy, the functioning of general social institutions for the inclusion and incorporation of them are examined under the assumption that such a national frame sets conditions or even determines processes of integration everywhere in the country and at all levels. There is an abundance of such national case studies, also monitoring and benchmarking policies and funded by policy agencies (for an analysis of the policy-research nexus, see Scholten et al., 2015). There is also an established tradition of comparative studies of countries and their integration models (starting with Hammar /1985/, Brubaker /1992/ and Castles /1995/).

While traditionally integration research has focused on the national level, over the past decades growing attention has been given to the emerging role of cities. The "local turn of integration policies" (Caponio and Borkert, 2010) has been explained as a consequence of globalisation and the loss of importance of the nation-state (Penninx, 2008), as a result of decentralisation processes (Schmidtke, 2014) or simply because immigrants tend to settle in urban areas and therefore it is precisely there where the challenges are most pronounced (Penninx, 2009). Often in contrast to highly symbolic debates at the national level, local policies have been characterised by a rather "bottom-up place sensitive approach" and a "pragmatic logic of problemsolving" (Scholten and Penninx, 2016). Whereas this may lead to inclusion in some instances and exclusion in others (Mahnig, 2004), several scholars argue that local policies are more likely to provide immigrants with equitable opportunities, accommodate ethnic diversity and work with immigrant organisations, which in turn would facilitate a greater degree of immigrant political participation.

Just like in the case of national policies, the study of local integration policies has started with many city monographs, followed later by more interesting comparative studies within and across national borders. Most of these early comparative studies have focused on a particular policy domain and a few cases. The first studies focused on the political dimension of integration and policies related to civic and political participation (e.g. Ireland, 1994; Rex and Samad, 1996; Blommaert and Martiniello, 1996; Garbaye, 2000; Bousetta, 2001; Fennema and Tillie, 2004). Other comparative studies focused on specific aspects of local policy such as housing and segregation 
patterns (Musterd, Ostendorf and Breebaart, 1998), policing (Body-Gendrot, 2000), the institutionalisation of Islam (Rath et al., 2001) or the management of diversity in the implementation of local policies (Moore, 2001). In more recent years there have been a diversification of topics and cases, including studies on policy areas such as employment (Aybek, 2010; Vermeulen and Stotijn, 2010), education (Bruquetas-Callejo, 2014) or de-radicalisation (Van Heelsum, 2011) and taking cases beyond the more traditionally studied Western European cities (Crul and Holdaway, 2009; Foner et al., 2014; Schmidtke, 2014).

Despite the growing attention to the emerging role of cities since the 1990s, systematic city comparisons along all policy domains have been rare until 2003. One of the exceptions was the UNESCO-MOST project "Modes of Citizenship and Multicultural Policies in European Cities" (MPMC, 1996-2004). This project focused on the political participation of immigrants but this specific focus was framed in a more general comparison of cities, their immigrants and local governmental policies. Systematic descriptions were made of 16 major European cities and Tel Aviv. In two book publications (Rogers and Tillie, 2001; Penninx et al., 2004) general comparison of policies and cities were supplemented by in-depth comparisons on selected topics. Alexander used this material not only to construct a first typology of local policies (Alexander, 2004) but also to develop an in depth comparison of policies on the basis of the cases of Amsterdam, Paris, Rome and Tel Aviv (Alexander, 2007).

The field of (comparative) studies of local integration policies changed fundamentally after 2003. By that time three developments came together. Firstly, more and more cities not only had developed local integration policies, but also started to exchange knowledge and experience within networks of cities, nationally and across national borders. Secondly, the European Union started to become an active partner in integration policies, developing strong relations with cities, promoting and financing networks of cities and generously funding research on local policies. Thirdly, as the topics of immigration and integration became more politicised on the national level, relations of cities with national authorities and their immigration and integration policies became more problematic (division of competences, implementation tasks and financial resources for policies). All this created a context that was favourable for comparative policy research.

In this contribution we will try to capture two main elements that have emerged from these studies and particularly from the comparative research projects. The first relates to the question how we should study integration 
processes and policies related to these processes. The second element relates to the content of local integration policies: what kind of policies do cities have, that is, what are the fundamental policy measures in the legal/political, socio-economic and cultural/religious domains and how do cities combine these different dimensions. We will also consider how they frame and sell their policies. We aim to identify the common context and horizon of all cases of local integration policies while at the same time illustrating their differences in approach.

In order to answer these questions systematically, we define in the next section briefly the concept of integration, introducing an open non-normative analytical definition and identifying the main dimensions, parties involved and levels of analysis ${ }^{1}$. In section 3, we then define integration policies, their frames and concrete policy measures. In section 4 , we focus on local integration policies, describing the multilevel governance context that positions cities in relation to national and supra-national policymakers and at the same time enhanced strongly the comparative study of local policies $^{2}$. Section 5 goes into the content of these policies, analysing the main policy measures in the legal/political, socio-economic and cultural/religious domains. In the conclusions we come back to our initial question, i.e. what kind of policies cities have, outlining trends of convergence and divergence on local integration policies in Europe.

\section{THE STUDY OF INTEGRATION PROCESSES}

We define integration as the process of becoming an accepted part of society. This elementary definition is intentionally open in two regards. First, it emphasizes the process character of integration rather than defining an end situation. Second, in contrast to the normative models developed by political theorists, it does not specify beforehand the degree of or even the particular requirements for acceptance by the receiving society. This makes the definition highly useful for empirical study of these processes. Measuring the degree of becoming an accepted part of society will allow us to capture the diversity of (stages of) the process. We do need to specify within this basic definition what should be measured; that is, what are the indicators of integration and where might we find them.

We find indicators of integration processes in three analytically distinct di-

1 The sections 2 and 3 on the concepts of integration processes and policies are based on Penninx and Garcés-Mascareñas, 2016, chapter 2.

2 This section is based on Penninx (2015) and Scholten and Penninx (2016). 
mensions in which people may (or may not) become accepted parts of society: (i) the legal/political, (ii) the socio-economic, and (iii) the cultural/religious one. The legal/political dimension refers to residence and political rights and statuses. The basic question here is whether and to what extent are immigrants regarded as fully-fledged members of the political community. The position of an immigrant or the "degree of integration" has two extreme poles. One of these is the position of the irregular immigrant who is not part of the host society in the legal/political sense, though perhaps being integrated in the other two dimensions. The other is the position of the immigrant who is (or has become) a national citizen. In between there is enormous variety, which has increased in recent decades as a consequence of attempts of European states to "regulate" international migration and the new statuses and rights stemming from the EU migration regime (among others, EU nationals versus third-country nationals or "TCNs").

The socio-economic dimension refers to the social and economic position of residents, irrespective of their national citizenship. Within this dimension, the position of immigrants can be analysed by looking at their access to and participation in domains that are crucial for any resident. Do immigrants have equal access to institutional facilities for finding work, housing, education, and health care? Do they use these facilities? What is the outcome of immigrants' participation compared to that of natives with the same or comparable qualifications? Since needs and aspirations in these domains are relatively universal (basic needs are largely independent of cultural factors), access to and participation of immigrants and natives in these areas can be measured comparatively. The outcomes, particularly when they are unequal, provide useful inputs for policies.

The cultural/religious dimension pertains to the domain of perceptions and practices of immigrants and the receiving society as well as their reciprocal reactions to difference and diversity. If newcomers see themselves as different and are perceived by the receiving society as culturally or religiously different, they may aspire to acquire a recognized place in these respects. For their part, the receiving society may or may not accept cultural or religious diversity. Here again we find two extremes. At one extreme, new diversity may be rejected and immigrants required to adapt and assimilate into mono-cultural and mono-religious societies. At the other extreme, ethnic identities, cultures, and world views may be accepted on an equal level in pluralistic societal systems. Between these two extremes again are many in-between positions, such as accepting certain forms of diversity in the private realm but not, or only partly, in the public realm. 
Figure 1. A heuristic model for the empirical study of integration processes

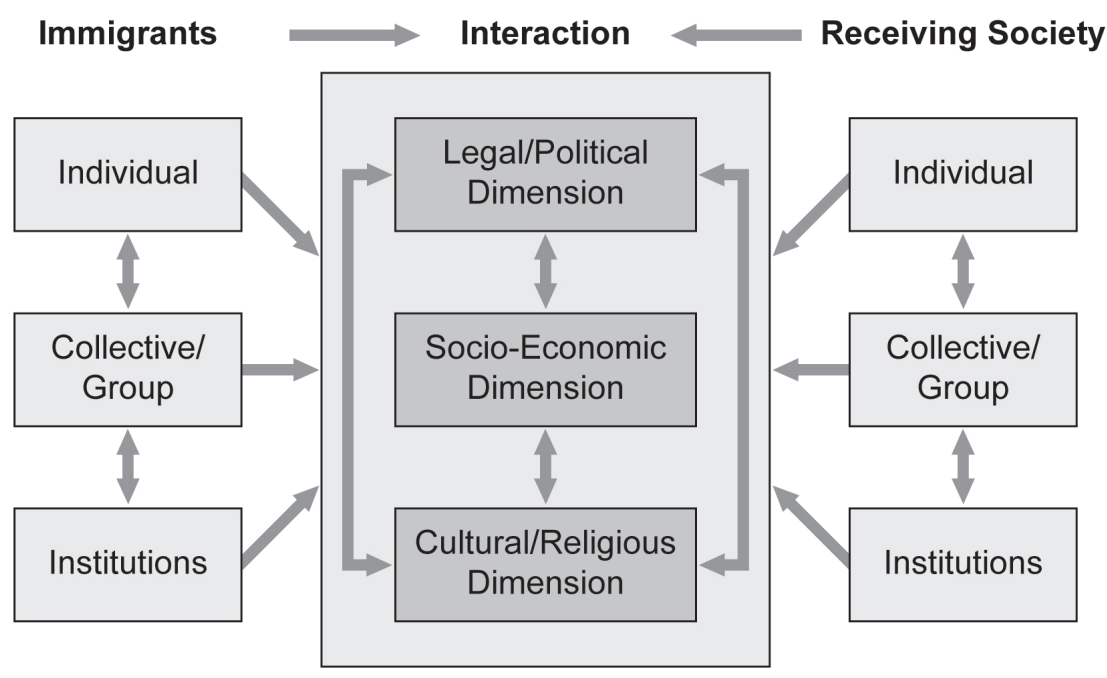

Having defined the dimensions of the process of integration of newcomers into an established society and how to measure them, the next question is who are the relevant parties involved? Firstly, there are the immigrants themselves, with their varying characteristics, efforts, and degrees of adaptation (the left part of Figure 1). Secondly, we find the receiving society, with its characteristics and reactions to the newcomers (the right part of Figure 1). It is the interaction between the two, however, that determines the direction and the temporal outcomes of the integration process. However, these two "partners" are fundamentally unequal in terms of power and resources. The receiving society, especially its institutional structure and reaction to newcomers, is far more decisive for the outcome of the process than the immigrants themselves are.

Processes of immigrants' integration take place and can be measured at different levels. The first level is that of individuals, both migrants and natives of the receiving society. For the first dimension, immigrants' integration at the individual level can be measured in terms of their legal status and political participation. For the second dimension, we can look at their socio-economic integration and position in the "hard" domains of housing, work, education, and health. For the third dimension, we would measure their identification with a specific cultural/religious group and with the receiving society, as well 
as their cultural and religious practices and how these are valued. In our conceptual definition of integration, we should also measure the attitudes and behaviour (or acceptance) of native individuals towards newcomers and the consequences of these.

The second level is that of organizations. There are the organizations of immigrants, which mobilize resources and ambitions of the group. These organizations may be strong or weak; they may orient themselves primarily towards (certain aspects of participation in) the receiving society or to specific cultural and religious needs of the group. They may become an accepted part of civil society - and a potential partner for integration policies - or isolate themselves or be excluded by the host society. There are also organizations of the receiving society. Their extent of openness to newcomers, their perceptions of and behaviour towards individual immigrants and their organizations might be of crucial importance for immigrants' integration. Research has shown, for example, that with the absence of governmental integration policy in Germany until 2002, NGOs, particularly trade unions and churches, played a crucial role in the integration processes of guest workers and their families (Penninx and Roosblad, 2000).

The third level is that of institutions, understood as standardized, structured, and common ways of acting in a socio-cultural setting. Two kinds of institutions are of particular relevance. The first are the general public institutions of the receiving society in the three dimensions: institutional arrangements of the political system; institutional arrangements in the labour market, housing, education, and public health; and institutional arrangements for cultural and religious diversity. Laws, regulations, and executive organizations, but also unwritten rules and practices, are part of these institutions. Though general institutions are supposed to serve all citizens in an equal manner, they may impede access or equitable outcomes for immigrants.

The second type of institution that is particularly relevant for immigrants' integration is institutions specifically "of and for" immigrant groups, such as certain religious or cultural ones. Unlike general institutions, the value and validity of any group-specific institution is confined to those who voluntarily choose and adhere to them. Although their place is primarily in the private sphere, group-specific institutions may also manifest themselves in the public realm as civil society actors, as the history of churches, trade unions, cultural, leisure, and professional institutions in European cities and states shows. Some migrant-specific institutions may become accepted parts of society, equivalent to institutions of native groups. Others, however, might either isolate themselves or remain unrecognized or even excluded. 


\section{THE STUDY OF INTEGRATION POLICIES}

The study of policies is fundamentally different from the study and understanding of the processes that such policies aim at. The essence of policies is that they intend to guide and steer processes in society, in our case, integration processes of immigrants. Explicit integration policies are part of a political process of a normative nature in which the issue of integration is formulated as a problem, the problem is given a normative framing and concrete policy measures are designed and implemented to reach a desired outcome. Other policies not specifically targeting immigrants, such as policies for education and health, housing, the labour market or the public regulation of religion) may exert a strong influence (positive or negative) in integration processes of immigrants. Therefore a systematic analysis of integration policies should go beyond integration policies in the strict sense.

When studying integration policies, the first question to be analysed is how different political and social actors perceive immigrant integration in terms of policy frames and policy shifts. A frame is (a reconstruction of) the problem definition of a policy issue, including the underlying assumptions of its causes and the remedies for it. This means looking at how the problem is actually defined and explained and what could and should be done. In terms of problem definition, it should be considered how immigration is perceived: is it seen as a problem or as opportunity? Who has the moral and/or legal right to be/become an immigrant? Who are the wanted and unwanted immigrants? For immigrants who are actually present in the host society, the basic question is whether they are seen as "foreigners", as "temporary guests" or as permanent members of the society for whom the state accepts the same responsibilities as for native citizens, guaranteeing the same rights and providing the same facilities.

Once the problem has been defined, the next step to be considered is what should be done. In some cases, a state or a city may choose to ignore immigrants' presence and therefore avoid any special responsibility for them. This is thus a choice for a non-policy response, which as such should be understood as a policy in itself (see Hammar, 1985: 277-278; Alexander, 2007: $37 \mathrm{ff})$. In other cases, new policies may be formulated to cater for certain immigrants' needs but under specific conditions due to the alleged temporary nature of their stay. Under this guest worker approach immigrants' otherness may be "tolerated" and even encouraged though their (residence) rights may be curtailed in the long run. Finally, if immigrants are perceived as permanent residents, inclusion may be the main response. This can be 
done in different ways though. Just like in the case of national integration policies (see Entzinger, 2000), integration policies may differ significantly with regard to the three dimensions of immigrants' integration identified above.

In terms of legal recognition and political participation (the legal/political dimension), policies may recognise immigrants as permanent foreign residents (the so-called denizens), thus incorporating them socially but limiting their political rights, or as full citizens, thus removing all barriers for naturalization. In terms of equality (the socio-economic dimension), policies may devise specific measures catering for immigrants' concrete interests and needs or they may just act on the common interests of citizens in general. Finally, in terms of diversity (the cultural/religious dimension) policies may be designed under two very different premises: one is that integration demands the adaptation and learning of immigrants but also significant changes in the working of institutional structures of the host society (here integration is a two-way-street leading to mutual adaptation); the other is, that societal rules and structures, including underlying norms and values, should be taken as a given and immigrants should (voluntarily or even as a mandatory task) adapt to them (a one-way-street that leads to assimilation).

Finally, the third question to be addressed is for whom integration policies are meant. Migrant integration policies that formulate specific groups of immigrants as target groups are different from policies that focus on all immigrants and they are even more different from policies that target all individuals regardless of their origin or that target at natives, at established civil society and at general institutions of society. In practice these different approaches result in very different policies again with regard to the three dimensions of integration: political rights can be granted to immigrants as individuals, for instance by granting voting rights, or as members of a group, which often means the creation of representative bodies; policies may seek to promote equal opportunities for all citizens, meaning equal access to housing, education, health care and the labour market, or even equal outcomes in the distribution of these goods and services; finally, cultural diversity can be promoted as an individual or as a group right, the latter often implying the state support to immigrants' organisations and own institutions.

Frames cannot always be analysed directly but have to be reconstructed from policy documents and political discourses. When a policy is defined, there is generally an explicit formulation of a perceived problem and of the desired outcome of the specific efforts that are taken by policies. Such ver- 
bal, politically debated statements in and about policy documents contain the essential elements of policy frames. The most important elements to be studied and compared are: general assumptions and orientations on causes of the problem and remedies as well as basic concepts used (or explicitly rejected); general aims of policies and dimensions of integration addressed; and definition of the main target groups.

Policy documents may be closer to policy discourse than to policy practice. In this regard, it is fundamental to complement the study of policy frames with a concrete and detailed analysis of the actual policy measures. This means looking at the concrete programmes in place and again identify in which of the three dimensions of integration we find them, what their main goals are and who they target. As said before for integration policies in general, we should not limit ourselves to the analysis of explicit integration policy measures: programmes addressed to the population as a whole or to specific socio-economic groups regardless of their immigrant background as well as general institutional arrangements in areas such as education, health care, housing or the labour market may be as fundamental (or even more) in fostering (or not) the integration of immigrants. We should not overlook either how these policy measures are implemented in practice and, in particular, to what extent and how street-level bureaucrats, practitioners and professionals adapt them to their specific goals and (possibly limited) resources.

\section{THE MULTILEVEL GOVERNANCE RELATIONS OF LOCAL INTEGRATION POLICIES}

\subsection{European cities and their national connections}

Local integration policies have always been in the shadow of national integration policies or in the shadow of the absence of the latter, first of all because immigration policies (decisions about who is allowed to enter and stay) are made at the national level. If immigration policy is followed by a national integration policy, as happened in an early phase in Sweden (since 1975) and the Netherlands (since 1980), then local integration policies are stimulated and facilitated by such national policies. That is why Dutch and Swedish cities do have a longer history of local integration policies than other European cities. In these countries, the relationship between local and national policies took initially a specific shape. Cities became first implementers of nationally defined integration policies. As these cities started to feel the heavy pressures on essential institutions such as the housing sys- 
tem (segregation and degeneration of neighbourhoods), the labour market (disproportionate unemployment, high social benefit costs) and the education system (concentrations of ethnic minority pupils in certain areas and sectors), as well as on public order (racial harassment, crime, inter-group tensions), they joined forces to demand more executive power and greater resources from their national governments. In the face of concrete local challenges, these cities started to develop their own initiatives to complement national policies.

But immigration in Europe in the second half of the twentieth century was not necessarily followed by integration policy at the national level: most West European countries experienced significant immigration but did not enact national integration policies until the turn of the century. Nevertheless, immigrants did settle in cities and municipalities and some of these cities did develop integration policies, also in the absence of national policies. For example, most of the cities that the city of Amsterdam had invited to one of the first conferences on local integration policies in 1998 were cities that had pioneered local integration policies without the support of their national authorities: Antwerp, Berlin, Birmingham, Brussels, Copenhagen, Frankfurt a/M. Liège, London, Manchester, Madrid, Milan, Vienna and Zurich (Bestuurlijk Overleg Stadsdelen Amsterdam, 1998).

Swiss cities are interesting cases to illustrate how cities have developed local integration policies in a national context in which the concept of integration was non-existent (D'Amato and Gerber, 2005). Policy research played an important role in this: ethnologists at universities in the cities of Zurich, Bern and Basel conducted research on the integration of immigrants and - in collaboration with city authorities - developed so called "Integrationsleitbilder" (integration policy frames: Begert, 2005; Kessler, 2005; Tremp, 2005 ) in the second half of the 1990s. The cities presented their initiatives to national authorities in a joint conference, suggesting that the national government should have an integration policy and should support cities in their integration policies. However this suggestion was not taken up: it took several more years before the concept of integration (and a budget for policies) was introduced at the national level in Switzerland.

Whatever the history of local integration policies, a common characteristic during the last decade seems to be that tensions between cities and national governments developed or increased (see e.g. Scholten /2013/ for the Dutch case). One of these tensions relates to the implementation of (restrictive) immigration policies, particularly with regard to undocumented immigrants. While national policies tend to be more coherently directed to- 
wards their exclusion, local policies tend to be more pragmatic and inclusive vis-à-vis any person residing in the municipality. Disagreement between national and local authorities may also relate to the new reception policies, the civic integration courses and the increased cultural requirements for continued residence and for naturalisation: where national policies may be quite ideological in nature and strict in application on such matters, local policy practitioners tend to look more for feasible practical solutions that are acceptable in immigrant communities. Tensions between cities and national governments also arise when it comes to the financing of integration facilities. Where national policies do oblige cities to implement certain elements of integration policies, the question is who finances these efforts and whether financial allocations by national authorities are sufficient.

\subsection{EU integration policy and horizontal cooperation between cities}

During the last two decades, and specifically since 2003, European cities have developed significant new relations outside their national context, particularly in the form of networks of cities that exchange knowledge and practical experiences in local integration policies. Although such initiatives primarily aim at cross-national horizontal forms of cooperation between cities, all of these networks have strong connections with and receive financial and other support from the European Commission. A new coalition has emerged in the multi-level governance of migration and integration in Europe.

This new constellation goes back to the Amsterdam Treaty of 1997 and the Tampere Summit of ministers responsible for migration and integration policies in 1999. These had stipulated that asylum and migration should become a common EU policy domain, that existing migration policies and practices should be harmonised, and that third-country nationals who are long-term residents should be granted rights that approximate those of EUcitizens as closely as possible. In the first period of the Tampere Programme (1999-2004), EU policymaking concentrated strongly on the harmonisation of migration and asylum policies while integration was nearly absent (Van Selm and Tsolakis, 2004). In fact, until 2003 EU policies started from the implicit assumption that if the legal position of immigrants was made as equal as possible to national citizens (as the Tampere Programme stipulated), and if adequate instruments were put in place to combat discrimination, then integration processes could be left to societal forces. Thus, legal integration of TCNs was to be ensured by means of the directives on family 
reunification and free movement after five years on the one hand, and by anti-discrimination directives on the other.

It was only in 2003 that the European Commission came up with a more comprehensive view on integration policies in its Communication on Immigration, Integration and Employment. This Communication defined integration as "a two-way process based on reciprocity of rights and obligations of third-countries nationals and host societies that foresee the immigrant's full participation" (European Commission, 2003). This holistic policy approach targets all dimensions of integration (economic, social and political rights, cultural and religious diversity, citizenship and participation). In November 2004, the Council of Ministers responsible for integration agreed on the Common Basic Principles (CBP) for integration as a first step towards a common framework for a European approach to immigrant integration. ${ }^{3}$

In contrast to EU migration policies, which are governed by communitarian principles (first pillar), EU integration policymaking is on an intergovernmental basis (third pillar). This means that policies have to be decided through consensus of member states and there is no binding legislation and directives. This has two effects on the making of policies. On the one hand, national governments do protect their sovereign right to decide in many domains that are important in the broad concept of integration, like social security, education, housing and health. In this sense, EU integration policies are clearly "soft" policies and limited to what national governments allow them to be. On the other hand, through intergovernmental policymaking national governments may also try to transpose their national policies to the EU-level. Since 2004 some West European countries, for example, have increasingly "uploaded" ${ }^{4}$ their cultural integration requirements for new Third-country immigrants to EU-integration policies. The Netherlands and its civic integration courses are a good example: what had started in the Netherlands as voluntary toolkit programmes for early reception at the local level in the 1990s became first mandatory national civic integration courses in the 2000s in the Netherlands. These were promoted and gained currency in other EU member states after 2004, including testing and sanctions.

This shift to a very broad conception of integration, however, did not go together with a broadening of the target group: integration policies are supposed to be for third-country nationals only. Immigrants who are citizens from EU member states are supposed to be integrated by definition. The latter assumption has been criticised recently by local authorities in regions that received many new immigrants from accession states after the enlargements of 2004 and 2007 (Collett, 2013).

4 Hannelore Goeman uses this term in her analysis of the constitution of integration policies at the EU level (Goeman, 2012; see also Guild, Groenendijk and Carrera, 2009). 
Although this specific mechanism of policymaking and implementation is "soft" - the method is called the "open method of coordination" - the European Commission has managed to get agreement on some influential practical tools for concrete action. From 2004-2006 the INTI programme (Integration of third-country nationals) financed action and research, followed by two more substantial funds running from 2007 to 2013: firstly the European Integration Fund (EIF), and secondly the European Refugee Fund (ERF), designed especially to compensate actors in member states for their efforts regarding the reception and integration of refugees. For the European Commission as a policymaker, these funds are important, since they create direct relations between the EU and local and regional authorities (and their policies), on the one hand, and non-governmental civil society partners at all levels, on the other.

At the local level these funds have functioned in different ways: in Western Europe they permitted to continue funding long term established policies; in Southern Europe they were crucial for maintaining recently created policies in a context of severe economic crisis and consequent cuts to the national social policy budget (Caponio, 2014b, 2014c); in Central and Eastern Europe they served to put immigrants' integration policies into the local and national political agendas (Matusz-Protasiewicz, 2014a, 2014b). While cities used these funds to implement their own policies independently or despite national governments, these funds imposed particular EU policy priorities and target groups (e.g. third-country nationals) at the local and national levels.

In this context, a new coalition between the European Commission and new networks of European cities came into existence shortly after 2003. We describe the four most important networks and the involvement of research in these initiatives below (see also Penninx, 2015).

The first is the CLIP-Network (Cities for Local Integration Policies), ${ }^{5}$ established as a European Network of cities in 2006 by the Congress of Local and Regional Authorities of the Council of Europe, the City of Stuttgart and Eurofound. ${ }^{6}$ It comprises some 30 European cities. The basic idea of the CLIPproject is to learn by exchanging knowledge and experience between cities. This is done in a systematic process involving research institutes that collect material on integration policies in the participating cities. Five research

For more information on the network see: www.eurofound.europa.eu/about-clip.

6 The European Foundation for the Improvement of Living and Working Conditions (Eurofound) is a tripartite European Union Agency, whose role is to provide knowledge in the area of social and work-related policies. 
institutes of the IMISCOE Network of Excellence ${ }^{7}$ have been engaged to do case studies in each of the cities and to compare these cases. The project is organised as a suite of consecutive modules in which specific aspects of local integration policy are studied empirically and compared systematically. The first module was on housing for immigrants (Bosswick et al., 2007), the second on diversity policies in employment and service provision (Spencer, 2008), the third on inter-group relations (Lüken-Klassen and Heckmann, 2010), and the fourth on immigrant entrepreneurship (Rath et al., 2011). Each module generated some 25-30 case studies, one comparative synthesis report and specific policy briefs. Each module was followed by a conference in which the results were discussed among the cities involved and with a wider interested audience. CLIP was funded from 2006 to 2012 by the European Foundation. The CLIP materials focus strongly on policy practices, in particular sub-domains of integration policies, enabling analysis of the complete chain from policy formulation to implementation and results, showing the often strong dependence of such policies on the functioning of general institutions at the local and national levels. It also gives important insights into the administrative and bureaucratic mechanisms involved in policymaking and implementation.

The second network is Integrating Cities, ${ }^{8}$ a project (also since 2006) carried out by Eurocities, a large network of some 140 major European cities. Integrating Cities can be seen as a policy dialogue between Eurocities and the European Commission. The most important platform for dialogue between cities and the European Commission are the Integrating Cities Conferences (held in Rotterdam, Milano, Berlin, London, Amsterdam and Tampere respectively, 2008-2013). The network has developed the Eurocities Charter on Integrating Cities as a programme for city governance.

In terms of (policy) research, Eurocities has implemented a number of EU-funded projects on local integration as well as initiatives from the Eurocities' Working Group on Migration and Integration. The oldest of these projects was the INTI-Cities project that ran for eighteen months during 2007-2009. The project was about "Benchmarking Integration Governance in European Cities": peer reviews were used to assess integration policies in European cities. By measuring policies against a benchmark of high standards, it aimed at delivering expert-validated, comparative knowledge on

The five institutes involved in CLIP are the European Forum for Migration Studies (EFMS) at the University of Bamberg, the Centre on Migration Policy and Society (COMPAS) at the University of Oxford, the Institute for Migration and Ethnic Studies (IMES) of the University of Amsterdam, the Austrian Academy of Sciences and the Centre for Ethnic and Migration Studies (CEDEM) of the University of Liège.

8 For more information on the network see: www.integratingcities.eu/. 
local practices in twelve cities from nine EU member states. The final report (Niessen and Kirchberger, 2009) summarises benchmarks and recommendations.

The INTI-project was followed by the DIVE-project that had a different and narrower focus on the promotion of diversity and equality in local policies, examining how cities and municipalities can effectively implement diversity policies in management and employment policies led by principles of equality. The project was co-financed by the European Integration Fund. Empirical research was carried out on local integration policies through peer-reviews in four major European cities (Berlin, Rome, Amsterdam and Leeds). The results of the project, called "Cities Accommodating Diversity" (Moloney and Kirchberger, 2010) nurtured the Integrating Cities conferences of Berlin 2009 and London 2010 and contributed to the Cities' charter on the role of local government in the integration of migrants.

The MIXITIES-project (Making integration work in Europe's cities 20102012) built on the work developed by the INTI- and DIVE-projects. It aimed to develop peer reviews, structured exchange workshops, and toolkits to support cities in delivering the commitments of the Charter. The project focused on three key areas, namely anti-discrimination policy, diversity competences in public services and introductory courses for newcomers. Peer reviews were held on each of these themes respectively in the cities of Gent, Barcelona and Stockholm in 2011. The project's findings and recommendations were presented at the Integrating Cities conference held in Amsterdam in March 2012.

The third network is Intercultural Cities, ${ }^{9}$ a joint action of the Council of Europe and the European Commission started in 2008. It emerged from the White Paper on Intercultural Dialogue that the Council of Europe had submitted for the European Year of Intercultural Dialogue in that same year. The concept of the Intercultural City was developed earlier by the British think-tank Comedia. In 2004, Comedia conducted a two-year research programme in the UK, United States, Australia, New Zealand and Norway entitled "The Intercultural City: Making the Most of Diversity". It looked at cultural diversity as a source of innovation, creativity and entrepreneurship and how increased intercultural dialogue, exchange and activity can be the catalyst for such a process (Wood, 2009).

The Intercultural Cities strategy is a management strategy that publicly advocates respect for diversity and a pluralistic city identity. The Intercul-

9 For more information on the network see: www.coe.int/en/web/interculturalcities/. 
tural Cities Programme was developed and first applied in eleven European pilot cities and has evolved since then. The Programme develops tools such as the Intercultural Cities Index for cities to evaluate and develop their policies. It organises international conferences for cities to exchange experience.

The fourth network is a more specific horizontal cooperation initiative, the European Coalition of Cities Against Racism (ECCAR), ${ }^{10}$ established in 2004 upon the initiative of UNESCO. The aim of this coalition of cities is to share experiences in order to improve policies to fight racism, discrimination and xenophobia. Since 2008, its annual general conference is the main tool for exchange between cities. In the meantime, 104 municipalities from $22 \mathrm{Eu}-$ ropean countries have joined the network and adopted the "Ten-Point-Plan of Action".

These four European networks described above are all networks that have built up some form of organisation and continuity of cooperation. But apart from these, there have been numerous forms of cooperation of cities that have existed only during the period that they have been funded (mostly by EU-funds). Examples are ELCI - European Local Cooperation for Integration (2010) - an eighteen-month project funded by the European Integration Fund that aims to promote knowledge and understanding of the valuable role that migrant organisations could play in integration process. Another example is DELI - Diversity in the Economy and Local Integration - financed by the Council of Europe and the EIF. It focuses on migrant-owned small and medium size enterprises in the local economy. If we were to scrutinise the long list of projects funded by the ERF, the EIF and also the ESF (European Social Fund) for material relating to local integration of migrants, we would certainly find many more. The ESF in particular has funded a number of projects on local labour market integration and on entrepreneurship in which (im-)migrants have a significant place.

Finally, we mention here the KING-project (Knowledge for INtegration Governance $)^{11}$ because that project made the most recent state-of-the-art study of local integration policies on which we draw heavily in this chapter. This project, financed by the EIF and led by ISMU in Milan, organised a multi-disciplinary team of researchers in order to provide the EC with relevant knowledge for its future integration policy. A sub-team (in which the present authors) made a state-of-the-art of studies of local integration policies in Europe, followed by a comparative analysis of eight cities: Amsterdam, Barcelona, Milan, Prague, Stuttgart, Turin, Turku and Warsaw.

10 For more information on the network see: www.eccar.info/.

11 For more information on the project see: http://king.ismu.org/. 
Two main reports, a bibliography and eight case-studies can be found on the KING-ISMU-website.

In a recently published article, Dekker et al. (2015: 20) conclude that "there are indeed horizontal networks for policy learning between cities throughout Europe, yet the impact of horizontal policy learning on policymaking appears to be limited". This seems a rather superficial evaluation to us. Although we would agree that some cities use the horizontal platform to show their city policies rather than to learn, it cannot be denied that these network have influenced policy discourses and led to spreading of particular policy measures. For instance, Intercultural Cities has motivated several European cities to develop policy frames with an interculturalist orientation. Based on the experience of the French NGO, LICRA (Ligue Internationale Contre le Racisme et l'Antisémitisme) and thanks to the ECCAR network, several European cities have developed an anti-racist mobile phone application to report cases of racism and provide juridical and practical assistance. Another example of mutual learning is the C4i-Communication for Integration project: co-funded by the Council of Europe and the European Commission and based on the experience of Barcelona's Anti-rumour Strategy, it aims to counterbalance rumours, prejudices and stereotypes by providing evidence-based information. At present it is implemented in 11 European cities in Portugal, Spain, Sweden, Germany, Ireland, Poland and Greece.

Furthermore, city networks do not only work as platforms for horizontal policy learning but have also functioned to channel political pressures from the local to the European level. For instance, in May 2015 Eurocities published a political statement on asylum where cities gave support to the European Parliament resolution on the humanitarian crisis in the Mediterranean, while giving several recommendations regarding measures to facilitate the integration of asylum seekers and refugees at the local level, the need to share responsibility and solidarity across Europe (including the revision of the Dublin III regulation) and more funding for services provided at the local level. This political statement concluded: "as frontline service providers, often responsible for taking care of asylum seekers, city authorities should be directly involved by national and EU institutions in the implementation of the Common European Asylum System, sharing responsibilities and ensuring a fair distribution of effort across Europe". Following this publication, Eurocities was invited to join the European Parliament's LIBE (civil liberties, justice and home affairs) committee to present its recommendations on asylum and migration. Thus city networks do also func- 
tion as a "vertical venue" for local governments in their attempt to shape policies at the European and national levels.

\section{FRAMING AND CONTENT OF LOCAL INTEGRATION POLICIES}

How do local authorities frame their policies for immigrants and what is the actual content of local policies: what do they actually do? We will try to answer these questions by analyzing how the three dimensions (the legal/ political, the socio-economic and the cultural/religious one) are reflected in policy rhetoric and practice and how these dimensions relate to each other in the cities' policies. Although our analysis is based on the broad field of city studies, we will illustrate the results with examples from the KING-city studies that we did in 2014 (Penninx et al., 2014).

\subsection{The legal and political dimension}

National policies draw the boundary between citizens and non-citizens and define immigrants' legal status and their rights. Though the distinction between intra-European migrants, third-country nationals, refugees, asylum seekers and undocumented immigrants is drawn at the EU and national levels, it is particularly at the local level where these different statuses of immigrants translate into different access to rights and different target groups: some are entitled to the same social provisions as citizens, like EU citizens, while, at the other end of the spectrum, others are excluded from the most basic rights, such as undocumented migrants; some are considered the target per excellence of integration policies, while others are not even seen as foreigners and therefore not even counted as such. In this context, local authorities implement nationally defined administrative procedures, facilitate access to legal status and manage immigrants' entitlement to particular social provisions, integration policies and political rights. In the next paragraphs we analyse how cities use their discretionary power and how they possibly add their own input in the implementation of national policies.

Cities may be involved in the implementation of immigration administrative procedures. While in some countries these procedures are highly centralised, in others cities have formal prerogatives on immigration matters. Spain is a particular case in point. Any person living in Spain is obliged to register in the municipal census, which gives access to education and health care as well as to certain municipal services and social benefits. Local authorities are also responsible for reports on social inclusion and hous- 
ing, the former being essential for regularisation and the latter for family reunification. Although these are seen as purely administrative procedures, in practice the stipulated requirements are not always clearly defined by the law and its regulations. Different municipal practices lead to more or less inclusive outcomes in terms of access to social services and possibilities of regularisation and family reunification (see Garcés-Mascareñas, 2014). Switzerland is another case in point: local authorities have full responsibility on individual citizenship applications. This leads again to different policy outcomes as some Swiss municipalities present higher rejection rates than others (Helbling, 2008).

Most European cities work as well to facilitate access to legal status by raising awareness of its advantages or providing information on the required procedures. In terms of awareness, the German case is particularly illustrative: as the number of foreigners taking on citizenship has been falling in the past years, cities such as Berlin, Hesse, Hamburg and Stuttgart have carried out naturalisation campaigns (Caponio, 2014a). For instance, in Stuttgart the council started the naturalization campaign "PASS Auf, lass Dich einbürgern!"12 to promote and inform about naturalization among the 90,000 non-citizens eligible. This was done through posters with portraits of naturalized citizens talking about their experiences and motivation to apply for the German citizenship and through the organisation of information events. Within a few months the number of applications rose up to 15\% (Schwarz, 2014: 15). Either directly or through social and immigrant organisations, cities do also provide information and legal advice on the administrative procedures related to naturalisation, renewal of residence permit, regularisation, family reunification, deportation, information regarding marriage with nationals or help with housing and other social services. The more opaque and inaccessible the administration is (with unclear rules and higher discretionary practices), the higher seems to be the need for local authorities to inform immigrants and mediate between them and national authorities.

Different legal statuses translate into different rights and different access to social services. Though this is defined at the national level, local authorities enjoy a considerable room of manoeuvre to make these boundaries more or less inclusive. This is particularly the case with regard to undocumented immigrants. National governments in North-Western Europe have

12 The slogan means literally: "Pay attention, be naturalised". In German, there is an interesting play on words in the first part "PASS Auf", since the word Pass also means passport. It can thus also mean "Show your passport". 
stricter policies against irregular immigration and more means to force local authorities to comply. Still in practice many cities find ways to receive and assist them to a certain extent. For instance, the city of Amsterdam subsidises NGOs to provide elementary services to undocumented immigrants that the city itself is not allowed to provide. In the recent policy programme 2014-18 the city states that it will make a budget reservation to fulfil their obligation to care for asylum seekers who receive a final negative decision, e.g. introducing a bed-bath-and-bread-programme (Blom, 2014). In fact, this is not far from what we see in many Southern European cities such as Turin and Barcelona, where again NGOs and immigrant organisations provide those services the city is not supposed to offer to undocumented immigrants. The main difference in Southern European cities is that the boundaries of exclusion/inclusion are more blurred as immigrants go back and forth between illegality and legality and in the case of Spain undocumented immigrants are registered at the local level and enjoy formal access to particular social services.

Immigrants' categorisation is also renegotiated at the local level when defining the relevant target groups of integration policies. Several NorthWestern European cities have reported the problematic target group definition of the European Union, which limits integration policies to third-country nationals. As workers and family members of the new EU accessing countries are found in need of integration facilities, several cities have initiated specific programmes. For instance, the city of Amsterdam did form a special project group to handle problems of EU-migrants in the city. It is not the legal status itself that is problematic: indeed, the status should open a full range of opportunities and services on an equal footing with natives. What is problematic is the fact that the presence of these newcomers cannot always be digested immediately by institutions, collectives and individuals of the receiving city and newcomers have to acquire the knowledge and skills to find their place. As cities cannot use European funds (e.g. the European Integration Fund) and often also not national funds, they tend to invest their own resources in integration activities for this category and pressure their national governments. For instance, in Turku this pressure resulted in a new national regulation for employers to register workers from the EU to make them visible (Penninx, 2014).

Political rights are primarily defined at the national level. In countries such as the Netherlands and Finland foreign residents have active and passive local voting rights. In contrast, in most European countries this right is limited to nationals, EU citizens and citizens from third countries with 
specific bilateral agreements (e.g. several Latin American countries in the case of Spain). When foreign residents have voting rights, there is often a significant representation of elected Councillors with an immigrant background. However, it is difficult to establish the exact importance of such direct political participation. Respondents in Turku and Amsterdam, for example, seem to take this kind of participation for granted while not considering it as "representing" the immigrant community. At the same time these two cases show, however, that a significant representation of Councillors with an immigrant background may lead to specific policy initiatives in this field.

In all cases voting rights (be they extended to all foreign residents or not) do not automatically translate into equal political participation: in fact, the level of turnout among immigrants is systematically lower. To address this problem, some cities have launched campaigns to promote immigrants' political participation. For instance, Stuttgart has organised several information events during the last electoral campaigns. It is interesting to note that as local authorities consider that the city cannot run campaigns specifically targeting immigrants, these have been delegated to immigrant organisations. Example of this is the campaign "Go Vote", which was organised by the Turkish German Forum and targeted the population as a whole but in different languages, thus indirectly addressing those who are not proficient in German (Schwarz, 2014: 17).

As for indirect political inclusion, many European cities have invested (in the past or in the present) in consultative committees, platforms or councils to bring together stakeholders in integration policies. However, these bodies differ in their composition and to a certain extent in their function. Some committees primarily bring together immigrants (mostly coming from immigrant organisations) to represent the target group of policies. They are asked to function as a communication, mobilisation and evaluation agency between target groups and policymakers. The cases of Milan, Turin and Stuttgart suggest that overall such forms of representation - as a kind of alternative political representation - are rather vulnerable and do not last long. Other committees gather direct stakeholders in integration policies and have a primarily focus on mobilisation, policy instrumentation and implementation. Immigrant organisations are not included as representatives of a group but rather as relevant stakeholders. As the case of Barcelona shows, membership is rather based on expectations of contribution to policymaking or implementation or on the expectation that members scrutinise the administration's policies and practices. 
In terms of representation and involvement in policymaking and implementation, a tension may arise between (representatives of) immigrant organisations and NGOs that defend the interests of immigrants and provide them services. In the very first phase of immigrants settlement, such as in the Prague and Warsaw cases, interests of immigrants are - in the absence of strong immigrant organisations - defended by such native NGOs. As immigrant organisations develop in the course of time, these may (re-)claim such representing tasks and the resources that the government may make available for both representation and service provision. The outcome of such struggle is to a great extent dependent on choices that local authorities make. For instance, after the electoral victory of the Northern League in the early 1990s in Milan, immigrant organisations were marginalised vis-à-vis the more reliable and experienced Italian NGOs, which had been running most of the municipality services for immigrants' reception and assistance (Caponio, 2014b).

\subsection{The socio-economic dimension}

Policies aiming to foster the socio-economic incorporation of immigrants are highly institutionalised and mainly a matter of national governments. However, it is at the local level where most challenges and problems around the structural incorporation of immigrants are first felt. Therefore municipalities have also developed specific policies. Most local policies in the socio-economic domain do not target immigrants as such but rather the more generally disadvantaged by either providing them direct support or allocating more public resources in schools or neighbourhoods with a greater concentration of low-income households. This is particularly clear with regard to public housing projects, educational programmes and workfare policies, which aim to reduce dependency on welfare by promoting participation in the labour market. However, some local policies do target immigrants specifically. Some policies focus on recently arrived immigrants. Others target specific vulnerable groups such as victims of trafficking, unaccompanied minors, refugees and asylum seekers. Some seek to guarantee that migrants are not formally or informally excluded when accessing particular social provisions and the labour market (what we call equal access). Others aim to ensure equality in terms of use and policy outcomes (equal outcomes).

The cases of Southern and Eastern European cities make it clear that most local integration policies in the socio-economic domain started as reception policies. In Southern Europe they mostly focused on newly arrived immigrants, either undocumented immigrants or immigrants with a precarious 
legal status (i.e. temporary residents). In Eastern Europe the main target has been refugees and other specific groups such as Roma. Reception policies aim to equip recently arrived immigrants with the necessary knowledge and skills to find their place in the receiving society. This includes information and advice on legal procedures (e.g. recognition of diplomas and qualifications or access to the health care system or public housing), language and vocational courses and complementary programmes in education. Most local authorities have also developed programmes for vulnerable groups, for instance to provide temporary shelter or access to specific vocational courses. Similarly, local authorities do often grant some social rights to those most excluded, i.e. undocumented immigrants and rejected asylum seekers. This may include some form of access to health care, social housing or education.

The local incorporation of undocumented immigrants and (rejected) asylum seekers has been illustrated and measured by the practices of streetlevel bureaucrats - including school teachers, doctors, police officers and city hall workers - but also by regional and local policy decisions that warrant the formal recognition of undocumented immigrants as local or resident citizens (Chauvin and Garcés-Mascareñas, 2012). These decisions result not only from humanitarian concerns but also from placing other policy imperatives beforehand. While national governments are more concerned on security issues and immigration control, local authorities tend to be more interested in promoting social cohesion, public security and public health. In other words, municipalities are more concerned in knowing who resides in the city, in including any person into the health care system or in avoiding irregular housing than in questions related to immigration control, national sovereignty and citizenship.

Legal access does not automatically translate into equality. As it is welldocumented that immigrants may face particular barriers in the domains of housing, health care and the labour market and that immigrant children may underperform in schools, local authorities have also developed some policies to guarantee equality in terms of use and policy outcomes.

Policies in the housing sector are above all local policies. While most policies in this domain do not focus specifically on migrants but rather on households with low or middle incomes, local authorities have also developed particular measures to overcome or minimise ethnic discrimination as well as discrimination of migrants in the housing market. These may include, for instance, the setting up of mediating agencies between landlords and tenants or housing information services for migrants. Besides 
these measures, most European municipalities have developed broader polices on segregation and urban renewal. As ethnic segregation is often seen as a problem, cities have undertaken several measures such as quotas for specific groups of non-natives and housing or resettlement projects. A key question is whether these policies are primarily based on the principle of individual equal access to housing or rather on anti-segregation ideas on the ethnic group level and ethnic mixture in urban neighbourhoods. These two principles may work against each other.

Employment is generally a central concern of local authorities. Here again policies target the most generally disadvantaged, in this case those excluded from the labour market. However, as immigrants may face some specific limitations, local authorities do also target them specifically either through particular projects or in practice. Some projects provide vocational training for vulnerable categories of migrants such as unaccompanied minors, trafficked women or refugees. Others target young immigrants and second generation in disadvantaged social conditions. There are also projects that give counselling and assistance to immigrants who want to start their own business. Others target recently arrived immigrants by providing language courses, information about the standard channels of access to the job market, legal help for obtaining recognition of professional qualifications and short training courses. The case of Barcelona shows how, in a situation of economic crisis, reception programmes may become specific training and employability services for the immigrant population as a whole, whether they are new arrivals or not. Research on policy implementation has also shown that, even when local authorities reject targeting immigrants specifically, practitioners tend to adapt their programmes to the specificities of each group, thus targeting immigrants or particular immigrant groups in practice (Vermeulen and Stotijn, 2010).

Though education is a matter of national and regional governments, local authorities have set up particular initiatives to "repair" some of the problems produced or not given response to by national policies. Municipalities do sometimes finance extra-curricular activities to support pupils in risk of underachievement or students that have recently arrived. Some cities have also developed particular programmes to reduce migrant children's concentration in underperforming schools. Local NGOs are particularly active in this policy domain. As local policies, they focus on specific problems such as the transition from primary to secondary school or the level of school dropouts. As they mostly "work around" existing national policies rather than attempting to change them, most of their initiatives do 
also consist of extra-curricular activities such as offering private tutoring to immigrant students, organising language courses for their parents or promoting migrants students' access to university. According to Golubeva (2012: 6), their methods of advocacy are non-confrontational: "rather than disrupt cooperation with other stakeholders in their fields by posing demands for immediate policy change, they work through projects aiming at modest step-by-step change in the future". The same could be said for local policies in this domain.

Finally, though several reports have shown that there remain striking differences in health outcomes and that these have to do with language, communication, socio-cultural factors, "newness" and cultural difference (Norrendam and Krasnik, 2011), in most European countries migrants' health and access to health services are not addressed by specific policies. Some cities have developed soft measures such as interpreting services to facilitate medical attention or campaigns to inform newcomers on health services or to provide information about specific medical problems. Interestingly the few initiatives taken by local authorities in this domain are mostly focused on dissemination and communication strategies.

\subsection{The cultural and religious dimension}

Most European cities celebrate cultural diversity as part of their identity. Cultural diversity is often presented as something intrinsically positive for the city. As it is seen as an element of attraction, cultural diversity has become a commonplace in most urban marketing campaigns. The other key term in most local policy documents is interculturality. This term refers to a (normative) strategy rather than to a model to describe and analyse reality. Intercultural policies aim at making visible cultural diversity by fostering mutual knowledge, interaction and exchange. Policymakers argue that intercultural policies promote interaction between individuals with different cultural backgrounds instead of (the acceptance of) difference between different cultural groups, as multiculturalist and pluralist ideologies would do.

Intercultural policies promote exchanges and relations between cultural diverse individuals and groups. For instance, the City of Barcelona organises endeavours ranging from working with secondary school students on particular topics, to musical and sports projects fostering relations among young people of different origins, projects encouraging the use of libraries that stimulate reflection and debate on intercultural coexistence (GarcésMascareñas, 2014: 24). The City of Turin aims to foster social integration 
and community cohesion by opening the Neighbourhood's Houses (Case del quartiere) to immigrant associations. It has also set up a "civil service for young migrants" to support their civic participation at the neighbourhood level (Caponio, 2014c: 21). In Milan, in the context of the city initiatives for the 2014 EXPO event, immigrant associations and cultural groups started to be regarded as a resource for the city's international outlook. Therefore 500 organisations were invited to join the World Forum, where roundtables on specific issues such as "women and cultures", "museum of cultures" or "food and culture" were organised. In Stuttgart the organisation Forum of Cultures organises events such as a summer festival of the cultures or discussion series where speakers on topics of diversity and culture are invited. Similarly, the German Turkish Forum aims not at representing the Turkish people in Stuttgart but at living "the German-Turkish aspect" by bringing people together in the areas of culture, education and social affairs (Schwarz, 2014: 21). In most cities policy involvement in such activities and events tends to be indirect, by providing resources and facilities to social and immigrant organisations.

Beyond intercultural policies, most European cities do explicitly recognise the individual right to one's language, culture and religion. While this right forms the base line for cities, limitations are added such as "as long as these are not in conflict with general laws and regulations". In practice, the recognition of this right is relatively passive in the sense that local authorities often consider immigrants' language, culture and religion a private matter. For instance, immigrants' home languages and religions are seldom recognised in the educational curriculum of primary and secondary schools. In this context, some European cities have developed specific projects to offer basic courses on immigrants' languages. Another example of the relative low local authorities' involvement in the promotion of immigrants' culture is the management of religious diversity. For instance, while access to facilities for worship, festivities and special events is fundamental for the right of freedom of worship, many cities refrain to get involved invoking the principle of separation of Church and State. In consequence, the management of religious diversity is often left to the more hidden practices of street-level bureaucrats (for instance, when cultural and religious habits or prescriptions may have consequences for the accessing and making use of particular social provisions) and to the initiative of civil society and stakeholders.

To sum up, cultural diversity and interculturalism are the two key concepts of local integration policies. However, when we look at particular pol- 
icy measures, two observations should be made. First, under the discourse of interculturalism, local authorities seem to be more concerned about the promotion of intercultural relations and the public celebration of cultural difference - as part of city branding - than with the recognition and promotion of immigrants' own culture, language and religion. Second, while local integration policies put the emphasis on cultural diversity and the promotion of intercultural relations, policy measures in this field tend to be rather limited (in number and budget) while most efforts at the local level continue to be directed to the socio-economic integration of individual immigrants.

\section{CONCLUSIONS}

This exploration of the research literature on local integration policies leads us to conclude that the development of the comparative study of local integration can best be understood and interpreted in the context of the emergence of multilevel governance relations of European cities. Firstly, in terms of the emergence of local integration policies, cities and municipalities are historically more likely to start integration policies and use research (or any other form of systematic knowledge) to underpin their local policies when they are stimulated and supported to do so by their national government, as it is shown by the case of Swedish and Dutch cities since the 1970s and early 1980s.

However, while an active integration policy at the national level might thus increase the probability of a local integration policy and in its wake research on such policies to emerge, the absence of such a national policy does not prevent cities from developing local integration policies. A significant number of European cities did so in the 1980s and 1990s, often supported by research and research-policy dialogues. The case of the Swiss cities of Zurich, Bern and Basel in the late 1990s is a good example.

The increasing relevance of the multilevel governance of integration in Europe becomes clear after the European Union initiated its own integration policy in 2003. Although the European Commission has a very specific definition of integration and of target groups (which is certainly not always shared by cities), increasingly direct policy cooperation has come into existence between the European Commission and local authorities, bypassing the national governance level. In that new constellation of multi-level governance, an interesting form of research-policy dialogues has mushroomed: networks of European cities that evaluate and share their own practical 
knowledge, assisted in that process by researchers, and financed by the European Commission.

When it comes to the content of such local integration policies we have seen that in terms of framing, an important central orientation of local policies is to see immigration and its diversity as an asset for the city that should be used and exploited. The key terms in the discourse and rhetoric are cultural diversity and interculturality (meaning primarily to create positive relations between cultural divers groups and creating common ground).

If we look at policy measures, however, the key initiatives are in the socio-economic domain and relate to the structural integration of individual migrants. Whenever possible, this is done in general programmes for vulnerable groups, adapting these programmes in the implementation to specific needs of migrants.

The legal and political domain is particularly important when national rules limit political rights and participation, and cities look for alternative pathways for participation and engagement of immigrants in policies. Significant tensions may arise with national policies, when it comes to undocumented migrants in cities. The fact that intra-EU migrants do not qualify for integration measures according to the EU-definitions is another problem for cities.

When it comes to the cultural/religious dimension of policies in practice, cities do in principle recognise individual cultural and religious rights for the private sphere (as long as they are within the law), but for the public sphere such rights are not leading. The key terms of cultural diversity and interculturality do not refer to individual rights but to the possible use of (certain forms of) cultural diversity for economic development or social cohesion. In the concept of interculturality a selective used concept of diversity (not all diversity is positive) is combined with a strategy that mobilises different stakeholders such as public institutions, business organisations, media, NGOs and immigrant organisations to manage diversity both for economic purposes and for societal cohesion.

Cities do make different choices both when it comes to the rhetoric and to the practical choice of policy measures in the three dimensions of policy. In that sense comparisons of local integration policies show a significant differentiation, which is to a great extent caused by the context of cities and their immigrants. It is not divergence, in the sense that policies do grow more apart. It is more because the institutional context into which migrants have to find a place and the characteristics, efforts and abilities of the migrants concerned do differ from the beginning from city to city. 
Where we see a certain form of convergence is in the multi-level governance structure of integration policies within the EU. Two elements seem to be important here. The first is that the politicised migration and integration issues have become a source of tension between national and local policies, admittedly varying in degree but still. The second is that EU integration policies have come to play an important role for local integration policies, both as a source of finance for policies and as an agency that stimulates horizontal cooperation and exchange of ideas between cities. The latter may eventually also lead to a certain convergence in the content of policies.

\section{REFERENCES}

Alexander, M. (2004). Comparing Local Policies toward Migrants: An Analytical Framework, a Typology and Preliminary Survey Results, in: R. Penninx et al. (eds). Citizenship in European Cities: Immigrants, Local Politics and Integration Policies. Aldershot: Ashgate, 57-84.

Alexander, M. (2007). Cities and Labour Immigration: Comparing Policy Pesponses in Amsterdam, Paris, Rome and Tel Aviv. Aldershot: Ashgate.

Aybek, C. N. (2010). Young immigrants' low participation in the German vocational training system: how local actors in Munich and Frankfurt/Main try to make difference, in: T. Caponio and M. Borkert (eds). The Local Dimension of Migration Policymaking. Amsterdam: Amsterdam University Press, 85-108.

Begert, U. (2005). Städteleitbild und migrationspolitische Erfahrungen der Stadt Bern, in: G. D'Amato and B. Gerber (eds). Herausforderung Integration: Städtische Migrationspolitik in der Schweiz und in Europa. Zürich: Seismo Verlag, 93-99.

Bestuurlijk Overleg Stadsdelen Amsterdam (1998). Ethnic Minorities and Local Government. Report of the Conference. Amsterdam: City of Amsterdam.

Blom, S. (2014). Local Migration and Integration Policies in Amsterdam. Fondazione ISMU - European Commission. (KING Project - Social Science Unit, KING In-depth Study n. 16/October 2014), http://king.ismu.org/wp-content/uploads/Blom_InDepthStudy. pdf (10 September 2016).

Blommaert, J. and Martiniello, M. (1996). Ethnic mobilization, multiculturalism and the political process in two Belgian cities: Antwerp and Liège, Innovation, 9 (1): 51-73, doi: 10.1080/13511610.1996.9968472.

Body-Gendrot, S. (2000). The Social Control of Cities?: A Comparative Perspective. Oxford: Backwell, doi: 10.1002/9780470712757

Bosswick,W., Lüken-Klaßen, D., and Heckmann, F. (2007). Housing and Integration of Migrants in Europe. Strasbourg: Council of Europe.

Bousetta, H. (2001). Immigration, Post-immigration Policies and the Political Mobilization of Ethnic Minorities: A Comparative Case Study of Moroccans in Four European Cities (PhD thesis). Brussels: Catholic University of Brussels.

Brubaker, R. (1992). Citizenship and Nationhood in France and Germany. Cambridge: Harvard University Press. 
Bruquetas-Callejo, M. (2014). Educational Reception in Rotterdam and Barcelona. Amsterdam: Amsterdam University Press.

Caponio, T. (2014a). The Legal and Political Dimension of Local Integration. Fondazione ISMU- European Commission. (KING Project - Social Science Unit, Desk Research Paper n. 9/July 2014), http://king.ismu.org/wp-content/uploads/Caponio_ DeskResearch.pdf (10 September 2016).

Caponio, T. (2014b). Integration Policies for Immigrants of the City of Milan, Italy. Fondazione ISMU - European Commission. (KING Project - Social Science Unit, KING In-depth Study n. 10/October 2014), http://king.ismu.org/wp-content/uploads/Caponio_ InDepthStudy10.pdf (10 September 2016).

Caponio, T. (2014c). Integration Policies for Immigrants of the City of Turin, Italy. Fondazione ISMU - European Commission. (KING Project - Social Science Unit, KING In-depth Study n. 11/October 2014) http://king.ismu.org/wp-content/uploads/Caponio_ InDepthStudy11.pdf (10 September 2016).

Caponio, T. and Borkert, M. (eds) (2010). The Local Dimension of Migration Policymaking. Amsterdam: Amsterdam University Press, doi: 10.5117/9789089642325.

Castles, S. (1995). How nation-states respond to immigration and ethnic diversity, New Community, 21 (39): 293-308, doi: 10.1080/1369183x.1995.9976493.

Chauvin, S. and Garcés-Mascareñas, B. (2012). Beyond Informal Citizenship: Exploring the New Moral Economy of Migrant Illegality, International Political Sociology, 6 (3): 241-259, doi: 10.1111/j.1749-5687.2012.00162.x.

Collett, E. (2013). The Integration Needs of Mobile EU Citizens: Impediments and Opportunities. Brussels: Migration Policy Institute Europe.

Crul, M. and Holdaway, J. (2009). Children of Immigrants in Schools in New York and Amsterdam: the Factors Shaping Attainment, Teachers College Records, 111 (Special Issue: Educating Immigrant Youth: Pathways to Employment and Citizenship in International Perspective): 1476-1507.

D'Amato, G. and Gerber, B. (eds) (2005). Herausforderung Integration: Städtische Migrationspolitik in der Schweiz und in Europa. Zürich: Seismo Verlag.

Dekker, R., Emilsson, H., Krieger, B. and Scholten, P. (2015). A Local Dimension of Integration Policies? A Comparative Study of Berlin, Malmö, and Rotterdam, International Migration Review, 49 (3): 633-658, doi: 10.1111/imre.12133.

Entzinger, H. (2000). The dynamics of integration policies: a multidimensional model, in: R. Koopmans and P. Statham (eds). Challenging Immigration and Ethnic Relations Politics: Comparative European Perspectives. Oxford - New York: Oxford University Press, 97-118.

European Commission (2003). Communication from the Commission to the Council, the European Parliament, the European Economic and Social Committee and the Committee of the Regions on immigration, integration and employment, COM (2003) 0336 final. Brussels.

Fennema, M. and Tillie, J. (2004). Do Immigrant Policies Matter? Ethnic Civic Communities and Immigrant Policies in Amsterdam, Liège and Zurich, in: R. Penninx et al. (eds). Citizenship in European Cities. Immigrants, Local Politics and Integration Policies. Aldershot: Ashgate, 85-106.

Foner, N., Rath, J., Duyvendak, J. W. and van Reekum, R. (2014). New York and Amsterdam: Immigration and the New Urban Landscape. New York: New York University Press, doi: 10.18574/nyu/9780814738092.001.0001. 
Garbaye, R. (2000). Ethnic minorities, cities and institutions: a comparison of the modes of management of ethnic diversity of a French and a British city, in: R. Koopmans and P. Statham (eds). Challenging Immigration and Ethnic Relations Politics: Comparative European Perspectives. Oxford: OUP, 283-311.

Garcés-Mascareñas, B. (2014). Local Integration Policies in Barcelona. Fondazione ISMU - European Commission. (KING Project - Social Science Unit, In-depth Study n. 12/October 2014), http://king.ismu.org/wp-content/uploads/GarcesMascarenas_ InDepthStudy.pdf (10 September 2016).

Garcés-Mascareñas, B. and Penninx, R. (eds) (2016). Integration Processes and Policies in Europe: Contexts, Levels, Actors. Dordrecht: Springer Open, doi: 10.1007/978-3-31921674-4, http://link.springer.com/book/10.1007\%2F978-3-319-21674-4 (15 September 2016).

Goeman, H. (2012). Integrating Integration. The Constitution of a EU Policy Domain on Migrant Integration (PhD thesis). Brussel: Vrije Universiteit Brussel.

Golubeva, M. (2012). Mapping European Stakeholders on Migrant Education. http:// www.eunec.eu/sites/www.eunec.eu/files/attachment/files/mapping20european 20stakeholders20on20migrant20education.pdf (23 January 2014).

Guild, E., Groenendijk, K. and Carrera, S. (eds) (2009). Illiberal Liberal States: Immigration, Citizenship and Integration in the EU. Farnham: Ashgate, doi: 10.4324/9781315587813.

Hammar, T. (ed.) (1985). European Immigration Policy: a Comparative Study. Cambridge: Cambridge University Press, doi: 10.1017/CBO9780511898143.

Helbling, M. (2008). Practising Citizenship and Heterogeneous Nationhood: Naturalisations in Swiss Municipalities. Amsterdam: Amsterdam University Press, doi: $10.5117 / 9789089640345$.

Ireland, P. (1994). The Policy Challenge of Diversity: Immigrant Politics in France and Switzerland. Cambridge, MA: Harvard University Press, doi: 10.4159/ harvard.9780674498839.

Kessler, T. (2005). Das Integrationsleitbild des Kantons Basel-Stadt, in: G. D'Amato and B. Gerber (eds). Herausforderung Integration: Städtische Migrationspolitik in der Schweiz und in Europa. Zürich: Seismo Verlag, 104-111.

Lüken-Klassen, D. and Heckmann, F. (2010). Intercultural Policies in European Cities. Strasbourg: Council of Europe.

Mahnig, H. (2004). The politics of minority-majority relations: how immigrant policies developed in Paris, Berlin and Zurich, in: R. Penninx et al. (eds). Citizenship in European Cities. Immigrants, Local Politics and Integration Policies. Aldershot: Ashgate, 17-37.

Matusz-Protasiewicz, P. (2014a). Warsaw: Evolution of Integration Governance. Fondazione ISMU - European Commission. (KING Project - Social Science Unit, KING Indepth Study n. 14/October 2014), http://king.ismu.org/wp-content/uploads/ MatuszProtasiewicz_InDepthStudy14.pdf (10 September 2016).

Matusz-Protasiewicz, P. (2014b). Prague: Evolution of Integration Governance. Fondazione ISMU - European Commission. (KING Project - Social Science Unit, KING Indepth Study n. 13/October 2014), http://king.ismu.org/wp-content/uploads/ MatuszProtasiewicz_InDepthStudy13.pdf (10 September 2016). 
Moloney, Th. and Kirchberger, A. (2010). Cities Accommodating Diversity: Findings and Recommendations from the Peer Review Project "Diversity and Equality in European Cities". http://www.migpolgroup.com/public/docs/171.Cities_AccommodatingDiversity_ DIVE_22.02.10.pdf (15 September 2016).

Moore, D. (2001). Ethnicité et Politique de la Ville en France et en Grande-Bretagne. Paris: L'Harmattan.

Musterd, S., Ostendorf, W. and Breebaart, M. (1998). Multi-Ethnic Metropolis: Patterns and Policies. Amsterdam: Kluwer Academic Publishers, doi: 10.1007/978-94-017-2365-7.

Niessen, J. and Kirchberger, A. (2009). Strategic thinking on equality and mobility. INTICities: Key findings and recommendations for European-level policy makers. Brussels, 27 January 2009, http://www.archive.migpolgroup.com/public/docs/150.INTI-Cities_ MPG_Presentation_BenchmarkingReport_28.01.09.pdf (23 January 2014).

Norrendam, M. and Krasnik, A. (2011). Migrants' access to health services, in: B. Rechel, et al. (eds). Migration and Health in the European Union. Berkshire: Open University Press.

Penninx, R. (2008). Migration and the City: Local Citizenship and Integration Policies, in: M. L. Fonseca (ed.). Cities in Movement: Migrants and Urban Change. Lisbon: Centro de Estudos Geográficos, University of Lisbon, 225-240.

Penninx, R. (2009). Decentralising Integration Policies - Managing Migration in Cities, Regions and Localities. London: Policy Network.

Penninx, R. (2014). Integration Policies for Immigrants of the City of Turku, Abo/Finland. Fondazione ISMU - European Commission. (KING Project - Social Science Unit, Indepth Study n. 9/October 2014), http://king.ismu.org/wp-content/uploads/Penninx_ InDepthStudy.pdf (10 September 2016).

Penninx, R. (2015). European cities in search of knowledge for their integration policies, in: P. Scholten et al. (eds). Integrating Immigrants in Europe: Research-Policy Dialogues. Dordrecht: Springer Open, 99-116, doi: 10.1007/978-3-319-16256-0_6, http://link. springer.com/book/10.1007/978-3-319-16256-0 (15 September 2016).

Penninx, R., Blom, S., Caponio, T., Garcés-Mascareñas, B., Matusz-Protasiewicz, P. and Schwarz, H. (2014). European Cities and their Migrant Integration Policies. A State of the Art Study for the Knowledge for Integration Governance (KING) Project. Fondazione ISMU - European Commission. (KING Project - Social Science Unit, KING Overview Paper n. 6/October 2014), http://king.ismu.org/wp-content/uploads/Penninx_ OverviewPaper6.pdf (10 September 2016).

Penninx, R. and Garcés-Mascareñas, B. (2016). The concept of integration as an analytical tool and as a policy concept, in: B. Garcés-Mascareñas and R. Penninx (eds). Integration Processes and Policies in Europe: Contexts, Levels, Actors. Dordrecht: Springer Open, 11-29, doi: 10.1007/978-3-319-21674-4_2, http://link.springer.com/bo ok/10.1007\%2F978-3-319-21674-4, (15 September 2016).

Penninx, R., Kraal, K., Martiniello, M. and Vertovec, S. (eds) (2004). Citizenship in European Cities: Immigrants, Local Politics and Integration Policies. Aldershot - Burlington: Ashgate.

Penninx, R. and J. Roosblad (eds) (2000). Trade Unions, Immigration, and Immigrants in Europe, 1960-1993: A Comparative Study of the Attitudes and Actions of Trade Unions in Seven West European Countries. New York - Oxford: Berghahn Books. 
Rath, J., Penninx, R., Groenendijk, K. and Meyer, A. (2001). Western Europe and Its Islam. Leiden - Boston - Cologne: Brill.

Rath, J., Swagerman, A., Krieger, H., Ludwinek, A. and Pickering, L. (2011). Promoting Ethnic Entrepreneurship in European Cities. Luxembourg: Publications Office of the European Union, http://www.eurofound.europa.eu/publications/htmlfiles/ef1138. htm (15 September 2016).

Rex, J. and Samad, Y. (1996). Multiculturalism and Political Integration in Birmingham and Bradford, Innovation, 9 (1): 11-31, doi: 10.1080/13511610.1996.9968470.

Rogers, A. and Tillie, J. (eds) (2001). Multicultural Policies and Modes of Citizenship in European Cities. Aldershot: Ashgate.

Schmidtke, O. (2014). Beyond National Models? Governing migration and integration at the regional and local levels in Canada and Germany, Comparative Migration Studies, 2 (1): 77-99, doi: 10.5117/cms2014.1.schm.

Scholten, P. (2013). Agenda dynamics and the multi-level governance of migrant integration: The case of Dutch migrant integration policies, Policy Sciences, 46 (3): 217-236, doi: 10.1007/s11077-012-9170-x.

Scholten, P., Entzinger. H., Penninx, R. and Verbeek, S. (Eds) (2015). Integrating Immigrants in Europe: Research-Policy Dialogues. Dordrecht: Springer, doi: 10.1007/978-3-31916256-0.

Scholten, P. and Penninx, R. (2016). The multi-level governance of migration and integration, in: B. Garcés-Mascareñas and R. Penninx (eds). Integration Processes and Policies in Europe: Contexts, Levels and Actors. Dordrecht: Springer Open, 91-108, doi: 10.1007/978-3-319-21674-4_6, http://link.springer.com/ chapter/10.1007/978-3-319-21674-4_6 (15 September 2016).

Schwarz, H. (2014). Local Integration Policies in Stuttgart, Germany. Fondazione ISMU European Commission. (KING Project - Social Science Unit, KING In-depth Study n. 15/October 2014), http://king.ismu.org/wp-content/uploads/Schwarz_InDepthStudy. pdf (10 September 2016).

Spencer, S. (2008). Equality and Diversity in Jobs and Services: City Policies for Migrants in Europe. Strasbourg: Council of Europe.

Tremp, J. (2005). Vom Integrationsleitbild zur Integrationspolitik der stadt Zürich, in: G. D'Amato and B. Gerber (eds). Herausforderung Integration: Städtische Migrationspolitik in der Schweiz und in Europa. Zürich: Seismo Verlag, 87-92.

Van Heelsum, A. (2011). Local policies of European cities on de-radicalisation, IMISCOE Conference "Ageing Migrants: Demography, Agency and Welfare", 7-10 September 2011, Warsaw, http://avanheelsum.socsci.uva.nl/2011\%20Heelsum\%20Cities\%20 Local\%20policies\%20on\%20Deradicalisation.pdf (10 September 2016).

Van Selm, J. and Tsolakis, E. (2004). EU Enlargement and the Limits of Freedom. Washington: Migration Policy Institute.

Vermeulen, F. and Stotijn, R. (2010). Local policies concerning unemployment among immigrant youth in Amsterdam and Berlin, in: T. Caponio and M. Borkert (eds). The Local Dimension of Migration Policymaking. Amsterdam: Amsterdam University Press, 109-134.

Wood, P. (ed.). (2009). Intercultural Cities: Towards a Model for Intercultural Integration. Strasbourg: Council of Europe. 


\title{
Integracijske politike europskih gradova u komparativnoj perspektivi: strukturne konvergencije i značajna diferencijacija
}

\author{
Rinus Penninx, Blanca Garcés-Mascareñas
}

\section{SAŽETAK}

Cilj je ovoga rada razmotriti komparativno istraživanje integracijskih politika europskih gradova. Prva dva dijela daju analitički okvir za istraživanje imigrantskih integracijskih procesa i politika čija je namjera upravljati takvim procesima. U trećem se dijelu izlaže kako su se razvile lokalne integracijske politike u odnosu na nacionalne politike i integracijske politike Europske unije, posebice nakon 2003. U četvrtom i glavnom dijelu analiziraju se oblikovanje i sadržaj integracijskih politika europskih gradova promatrajući njihovu različitost u pravnoj/političkoj dimenziji, zatim u društvenoekonomskoj dimenziji - uključujući područja rada, stanovanja, obrazovanja i zdravlja - kao i kulturnoj, religijskoj i etničkoj dimenziji. Autori zaključuju da postoji strukturna konvergencija u smislu da u složenoj strukturi višerazinskog upravljanja migracijama i integracijom gradovi zauzimaju sličnu poziciju razvijanjem horizontalnih odnosa suradnje i razmjene. Gradovi koji razvijaju izrazite integracijske politike skloni su to učiniti obuhvatnijim i pragmatičnijim uobličavanjem nego nacionalne politike i politike Europske unije. Istodobno postoji velika razlika u tome što gradovi zapravo čine: oblikovanje, namjere i mjere jako se razlikuju u pravnim/političkim i kulturnim/religijskim dimenzijama, dok je u društvenoekonomskoj dimenziji ta razlika manja kada je riječ o području djelovanja, ali je veća po jakosti političke intervencije.

KLJUČNE RIJEČI: politika prema migrantima, lokalna integracijska politika, višerazinske politike 